\title{
Model Spasial Perubahan Penggunaan Lahan dan Pengaruhnya Terhadap Kebijakan Swasembada Padi
}

\section{Dede Amrillah $^{1}$, Eko Kusratmoko² dan Supriatna ${ }^{3}$}

\author{
Ilmu Geografi, Fakultas MIPA, Universitas Indonesia ${ }^{1}$ \\ Departemen Geografi, Fakultas MIPA, Universitas Indonesia ${ }^{2,3}$ \\ Email koresponden : de2amri@gmail.com
}

Diterima: Januari 2018 /Disetujui: Februari 2018 / Publikasi online: Maret 2018

() 2018 Fakultas Geografi UGM dan Ikatan Geograf Indonesia (IGI)

\begin{abstract}
Abstrak perubahan tutupan dan penggunaan lahan di Kecamatan Kalitidu, Kabupaten Bojonegoro cukup signifikan khususnya untuk penggunaan lahan sawah. Suatu wilayah dikatakan berswasembada padi jika produksi berasnya lebih besar dibandingkan dengan angka konsumsi berasnya. Dalam penelitian ini dilakukan pemodelan spasial menggunakan metode jaringan saraf Multi-Layer Perceptron (MLP) dan Markov Chain (MC) yang terdapat dalam metode Land Change Modeler (LCM) pada perangkat lunak Idrisi. Pada pemodelan spasial tersebut digunakan variabel jalan sebagai faktor pendukung perubahan penggunaan lahan di tahun 2025. Hasil yang diperoleh dari pemodelan spasial tersebut yaitu besaran luasan sawah pada tahun 2025 dengan angka 4644.99 hektar dengan nilai akurasi 56.51\%. Kemudian nilai tersebut dikalikan dengan angka produktifitas padi tahun 2015 dan angka konversi gabah kering giling (GKG) menghasilkan nilai produksi beras di tahun 2025 sebesar 95705.37 ton. Angka konsumsi beras tahun 2025 sebesar 4648.402 ton didapatkan dengan mengkalikan jumlah penduduk di tahun 2025 yang memiliki angka 52515 jiwa dengan angka rata-rata konsumsi per kapita per tahun yang berada di angka 88.52 kg. Dengan demikian Kecamatan Kalitidu di tahun 2025 mampu berswasembada padi.
\end{abstract}

Kata kunci : model spasial, land change modeler, penggunaan lahan, multi-layer preceptron, rantai markov

\begin{abstract}
Kalitidu District, Bojonegoro Regency are significant, especially for paddy land use. A region is said to be self-sufficient in rice if its rice production is greater than its rice consumption rate. In this research, spatial modeling using Multi-Layer Perceptron (MLP) and markov chain method is applied in Land Change Modeler (LCM) method in Idrisi software. In spatial modeling used road variables as a driving factor the change of land use in 2025. The results obtained from spatial modeling is the size of paddy field area in 2025 with the number 4644.99 hectares with an accuracy of 56.51\%. Then the value is multiplied by the rate of rice productivity in 2015 and the conversion rate of dry milled grain (GKG) produces rice production value in 2025 of 95705.37 tons. The consumption rate of rice in 2025 amounted to 4648,402 tons was obtained by multiplying the number of population in the year 2025 which has the number 52515 people with the average rate per capita consumption per year which is at $88.52 \mathrm{~kg}$. Thus Kalitidu District in 2025 is capable of self-sufficient rice.
\end{abstract}

Keyword : spatial modelling, land change modeler, land use, multi-layer preceptron, markov chain

\section{PENDAHULUAN}

Padi merupakan salah satu komoditas pangan yang paling penting di Indonesia, oleh karena itu setiap daerah berkeinginan untuk tetap mempertahankan lahan sawah, baik sawah irigasi maupun tadah hujan, yang terdapat di wilayahnya. Kabupaten Bojonegoro salah satu daerah yang memproduksi padi dengan capaian angka pada kisaran 900 ribu ton per tahun. Dengan potensi tersebut maka Pemerintah Daerah Kabupaten Bojonegoro berkeinginan dalam mewujudkan wilayahnya sebagai lumbung pangan dan energi Indonesia yang produktif, berdaya saing, adil, sejahtera dan berkelanjutan sesuai dengan visinya. Hal tersebut berpengaruh terhadap kebijakan swasembada yang diterapkan oleh Kabupaten Bojonegoro dalam mempertahankan atau bahkan meningkatkan produksi pangan, secara khusus padi. Berdasarkan data Badan Pusat Statistik (BPS) Kabupaten Bojonegoro tahun 2016 bahwa luas lahan sawah yang dimiliki mencapai 78064 hektar atau 33,84\% terhadap luas wilayahnya. Perubahan penggunaan lahan dari lahan pertanian ke pemukiman menjadi kendala dalam mewujudkan swasembada pangan, diperlukan upaya yang keras agar lahan pertanian tidak berkurang.

Penelitian yang menggunakan metode MultiLayer Perceptron (MLP) dilakukan oleh Singh (2017) dan Vega (2012) dalam melihat perubahan tutupan dan penggunaan lahan pada wilayah hutan. Sementara itu, penelitian mengenai perubahan tutupan dan penggunaan lahan menggunakan MLP dan Markov Chain (MC) pada wilayah perkotaan atau pinggiran kota pernah dilakukan oleh Mishra (2014) di kota 


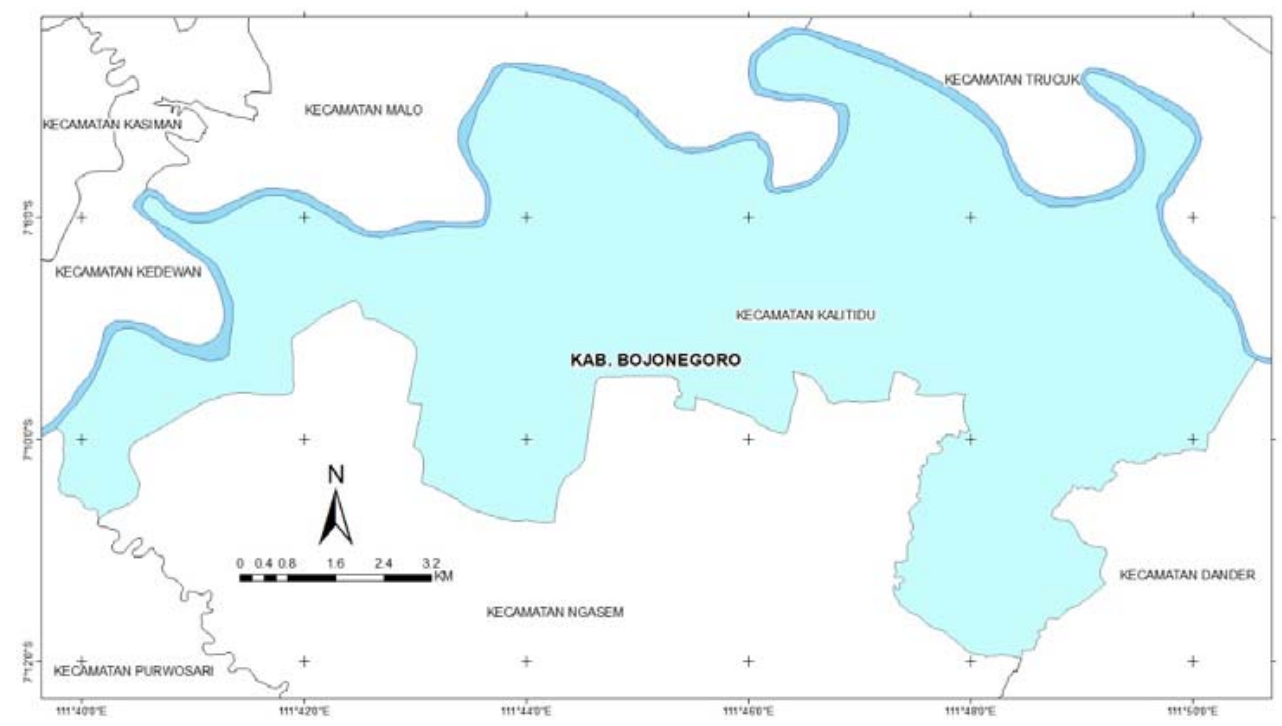

Gambar 1. Lokasi Penelitian

Muzaffarpur dan Mishra (2016) di distrik Patna yang keduanya di negara India, sementara itu penelitian di Indonesia dilakukan oleh Wardani (2016) di Kabupaten Bantul.

Tujuan dari penelitian ini adalah melihat kecenderungan perubahan penggunaan lahan dari tahun 2009 sampai dengan 2015 serta prediksinya pada tahun 2025 dengan menggunakan Land Change Modeler (LCM) dengan menggunakan metode MLP dan MC yang terdapat pada perangkat lunak Idrisi. Dari hasil pemodelan tersebut diperoleh luasan lahan sawah tahun 2025 yang pada proses selanjutnya akan dihitung kaitannya dengan kemampuan suatu wilayah dalam berswasembada padi.

\section{METODOLOGI PENELITIAN}

Penelitian ini difokuskan di Kecamatan Kalitidu, Kabupaten Bojonegoro (Gambar 1) dikarenakan sesuai dengan informasi yang didapatkan dari Pemerintah Daerah Kabupaten Bojonegoro bahwa kecamatan ini merupakan salah satu wilayah yang perubahan penggunaan lahannya cukup signifikan.

Data yang digunakan dalam penelitian ini yaitu citra satelit Landsat 5 tahun 2009 dan Landsat 8 tahun 2015 dengan path 119 row 65 yang diunduh melalui laman situs earthexplorer.usgs.gov, selain itu digunakan juga data Peta Rupabumi Indonesia skala 1:25000. Sementara itu data tabular produktifitas padi, jumlah penduduk, laju pertumbuhan penduduk, konsumsi beras per kapita dan angka konversi Gabah Kering Giling (GKG) diperoleh dari BPS Kabupaten Bojonegoro secara periodik mulai dari tahun 2010 sampai dengan 2015. Angka konversi GKG menjadi beras sebesar 62,74 persen yang sering disebut juga angka rendemen penggilingan lapangan (Rejekiningrum, 2013).
Dalam memproses data di atas digunakan perangkat lunak pengolah data, ArcGIS, ENVI, dan Idrisi.

Pada data temporal citra satelit Landsat dilakukan klasifikasi tutupan dan penggunaan lahan menggunakan ENVI yang menghasilkan 3 kelas yaitu sawah, lahan terbangun dan badan air. Alasan hanya dihasilkannya 3 kelas karena keberagaman tutupan dan penggunaan lahan di lokasi penelitian tidak banyak.

Setelah dilakukan klasifikasi, selanjutnya data tersebut dimodelkan menggunakan LCM. Dalam LCM terdapat tiga tahap yang harus dilakukan, diantaranya :

1. Analisa Perubahan (Change Analysis)

Pada proses ini dihasilkan perubahan lahan secara grafik maupun peta, sesuai dengan kelas yang terdapat pada data raster sebagai input.

2. Potensi Transisi (Transition Potensials) Tujuan utama dari tahap ini adalah untuk membuat peta potensi transisi dengan tingkat akurasi yang dapat diterima untuk menjalankan pemodelan yang sebenarnya (Mishra, Rai, \& Mohan, 2014). Terdapat tiga pilihan algoritma pemodelan yang digunakan untuk memodelkan variabel transisi ini yaitu regresi logistik, simweight dan MLP Neural Network.

Pada penelitian ini hanya MLP saja yang digunakan. Dalam Mishra, Rai dan Mohan (2014) pelatihan jaringan syaraf MLP didasarkan pada algoritma Backpropagation (BP) yang merupakan algoritma pelatihan yang diawasi atau terbimbing dan itu merupakan yang umum dalam melatih jaringan saraf tiruan.

3. Prediksi Perubahan (Change Prediction)

Data yang dihasilkan pada tahap sebelumnya digunakan untuk memprediksi tutupan 
dan penggunaan lahan tahun 2025 dengan menggunakan metode rantai markov. Rantai markov adalah metode yang umum digunakan untuk memodelkan perubahan tutupan lahan pada skala spasial yang beragam (Purwadhi, Kardono, Haryani, \& Poniman, 2015).

\section{Analisis Data Tabular}

Dari hasil pemodelan spasial, didapatkan prediksi luas lahan sawah untuk tahun 2025 yang kemudian digunakan untuk mendapatkan total produksi padi yang sebelumnya dikalikan dengan nilai produktifitas padi. Nilai produktifitas padi didapatkan dari nilai produktifitas padi tahun 2015. Untuk mendapatkan nilai produksi dalam satuan beras maka nilai produksi padi dikalikan dengan angka konversi GKG $(62,74 \%)$.

Data tabular lain yang dianalisa adalah data jumlah penduduk untuk mendapatkan angka jumlah penduduk di tahun 2025 digunakan rumus sesuai dalam Fuad, Ardiansyah dan Nuraeni (2016) :

$\mathrm{Pt}=\mathrm{P} 0(1+\mathrm{r})^{\mathrm{n}}$

dimana :

Pt : Penduduk tahun ke- $t$

P0 : Penduduk tahun ke-0

$\mathrm{r}$ : laju pertumbuhan rata-rata per tahun

$\mathrm{n}$ : tahun
Setelah didapatkan jumlah penduduk pada tahun 2025, dilakukan perhitungan konsumsi beras per kapita tahun 2025 dengan mengalikan jumlah penduduk dan rata-rata konsumsi beras per kapita per minggu. Data nilai konsumsi beras per kapita per minggu didapatkan dari BPS dimana nilainya berbeda setiap tahun, maka dari itu dilakukan rerata terhadap konsumsi beras per kapita per minggu ini. Nilai rata-ratanya adalah $1.702 \mathrm{~kg}$ per kapita per minggu, nilai tersebut jika dikonversikan dalam setahun menjadi $88.52 \mathrm{~kg}$ per kapita per tahun.

Dari dua analisis data tersebut maka akan dapat disimpulkan kaitannya suatu daerah berswasembada padi atau tidak dengan melihat nilai produksi beras hasil prediksi tahun 2025 dengan konsumsi beras per kapita tahun 2025.

Jika nilai produksi beras lebih besar dibandingkan dengan konsumsi beras maka daerah yang diteliti berswasembada padi, namun jika sebaliknya maka tidak berswasembada padi. Adapun alur kerja dari penelitian ini dapat dilihat pada Gambar 2.

\section{HASIL DAN PEMBAHASAN}

\section{Klasifikasi Citra}

Pengklasifikasian citra terbimbing pada tahap ini menggunakan metode klasifikasi maximum likelihood yang menghasilkan peta tutupan lahan dan penggunaan lahan (TLPL) dengan 3 kelas utama yaitu lahan terbangun, sawah, dan badan air untuk tahun 2009 dan 2015 (Gambar 3).

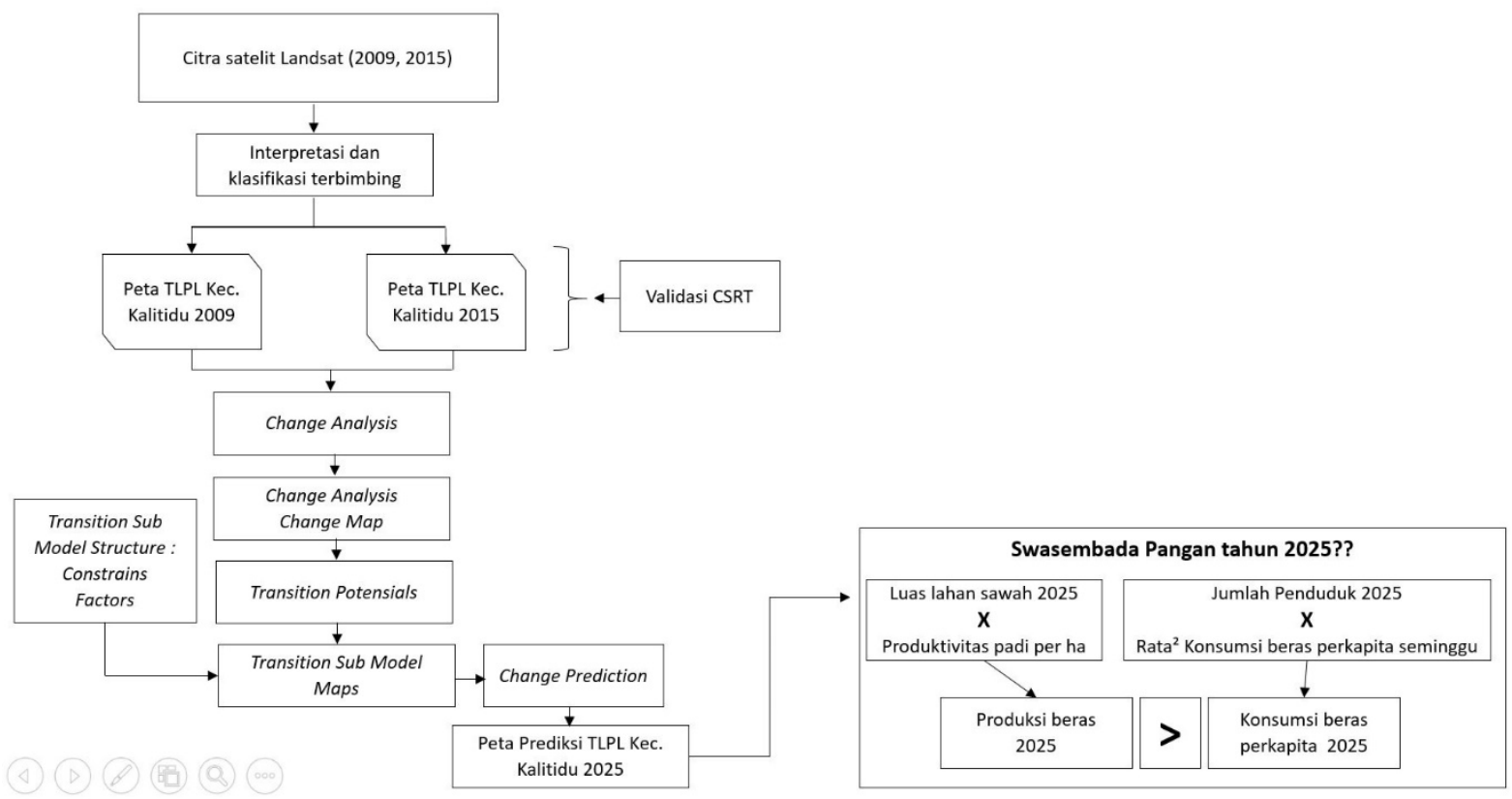

Gambar 2. Alur kerja penelitian 



Gambar 3. Peta TLPL tahun 2009 dan 2015

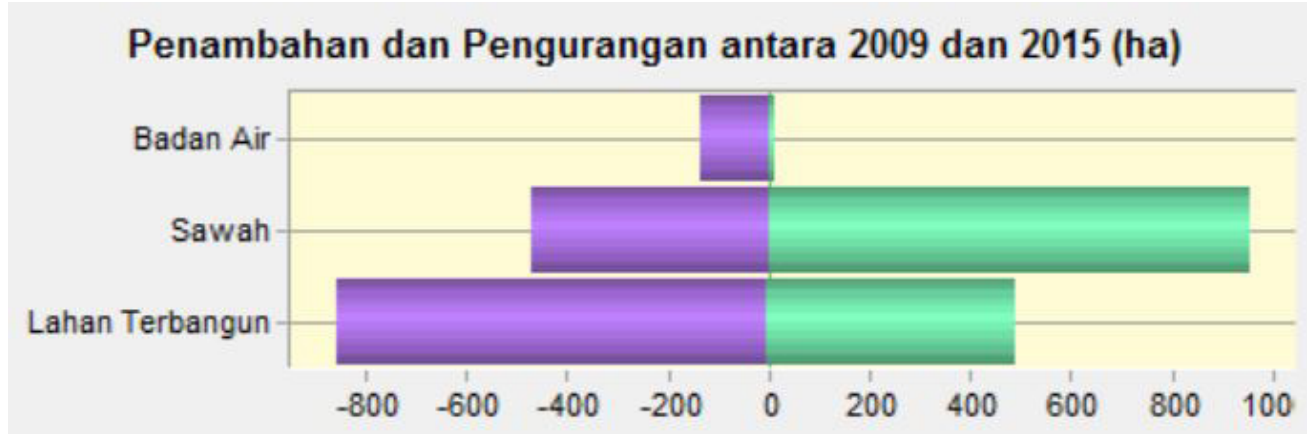

Gambar 4. Penambahan dan pengurangan kategori penggunaan lahan antara 2009 dan 2015

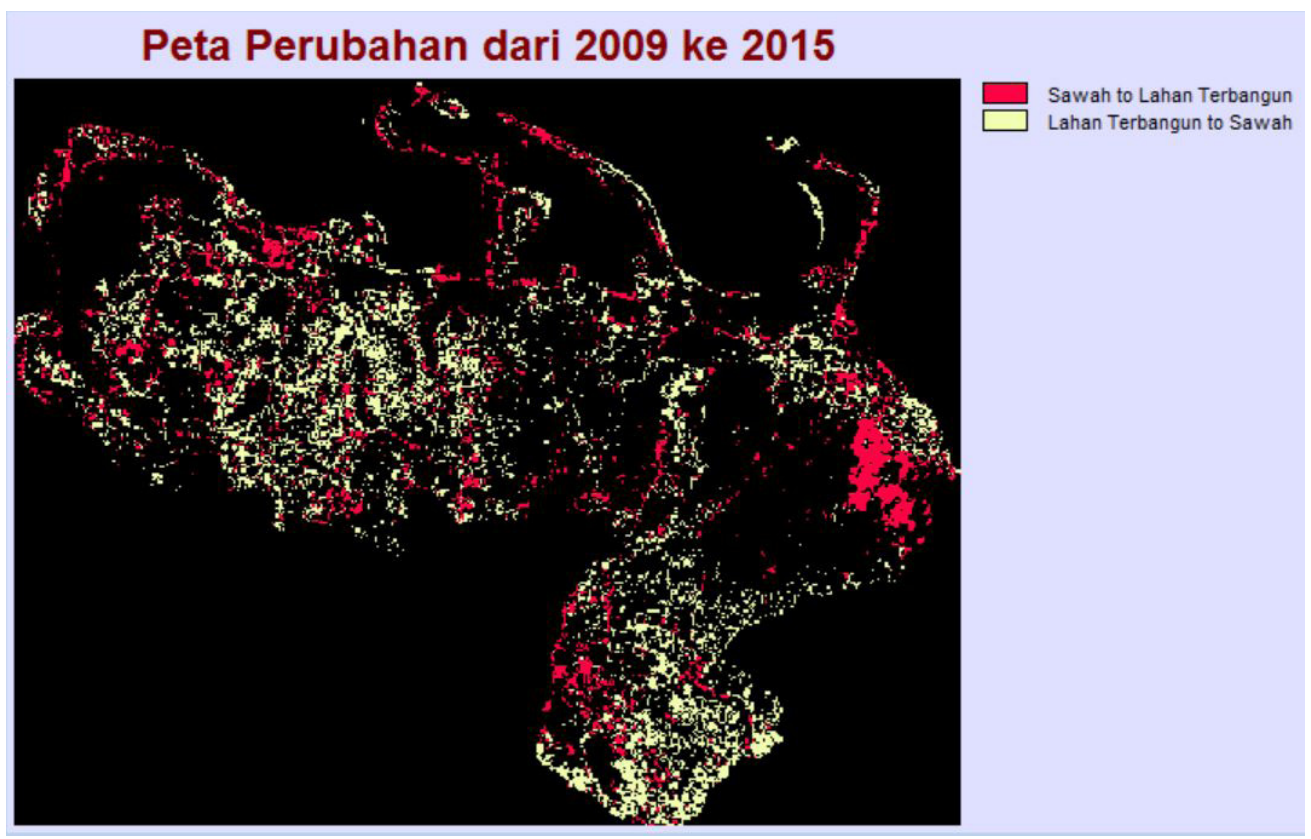

Gambar 5. Peta perubahan penggunaan lahan dari tahun 2009 ke 2015 


\section{Land Change Modeler (LCM)}

Tahap analisa perubahan memperlihatkan bahwa terjadi fenomena diluar kebiasaan dimana lahan sawah mengalami peningkatan sedangkan lahan terbangun justru mengalami penurunan dalam kurun waktu 2009 sampai dengan 2015 seperti terlihat pada Gambar 4. Selain itu dapat dilihat Gambar 5 peta perubahan yang dihasilkan dari dua peta TLPL 2009 dan 2015 dengan kriteria perubahan lahannya yang berada di atas 100 hektar.

Tahap potensi transisi dilakukan dengan memasukkan faktor pendukung yang dapat mempengaruhi perubahan lahan. Dalam penelitian ini digunakan variabel jalan sebagai salah satu yang mempengaruhinya. Algoritma pemodelan yang digunakan untuk memodelkan variabe transisi adalah MLP dengan memasukkan parameter iterasi sebenyak 10000. Hasil akurasi yang didapatkan dalam pemodelan ini sebesar 56.51\% (Gambar 6), menurut Eastman (2006) dalam Mishra, 2014, nilai disekitar 80\% masih dapat diterima.

Tahap terakhir dalam LCM adalah memprediksi TLPL di tahun 2025 dengan menggunakan metode rantai markov. Hasil yang didapatkan adalah peta prediksi TLPL tahun 2025 (Gambar 7) dengan luas sawah 4644.99 hektar, dan lahan terbangun 2055.06 hektar. Data tersebut akan digunakan dalam konversi nilai produksi padi.

Land Change Modeler : LCM

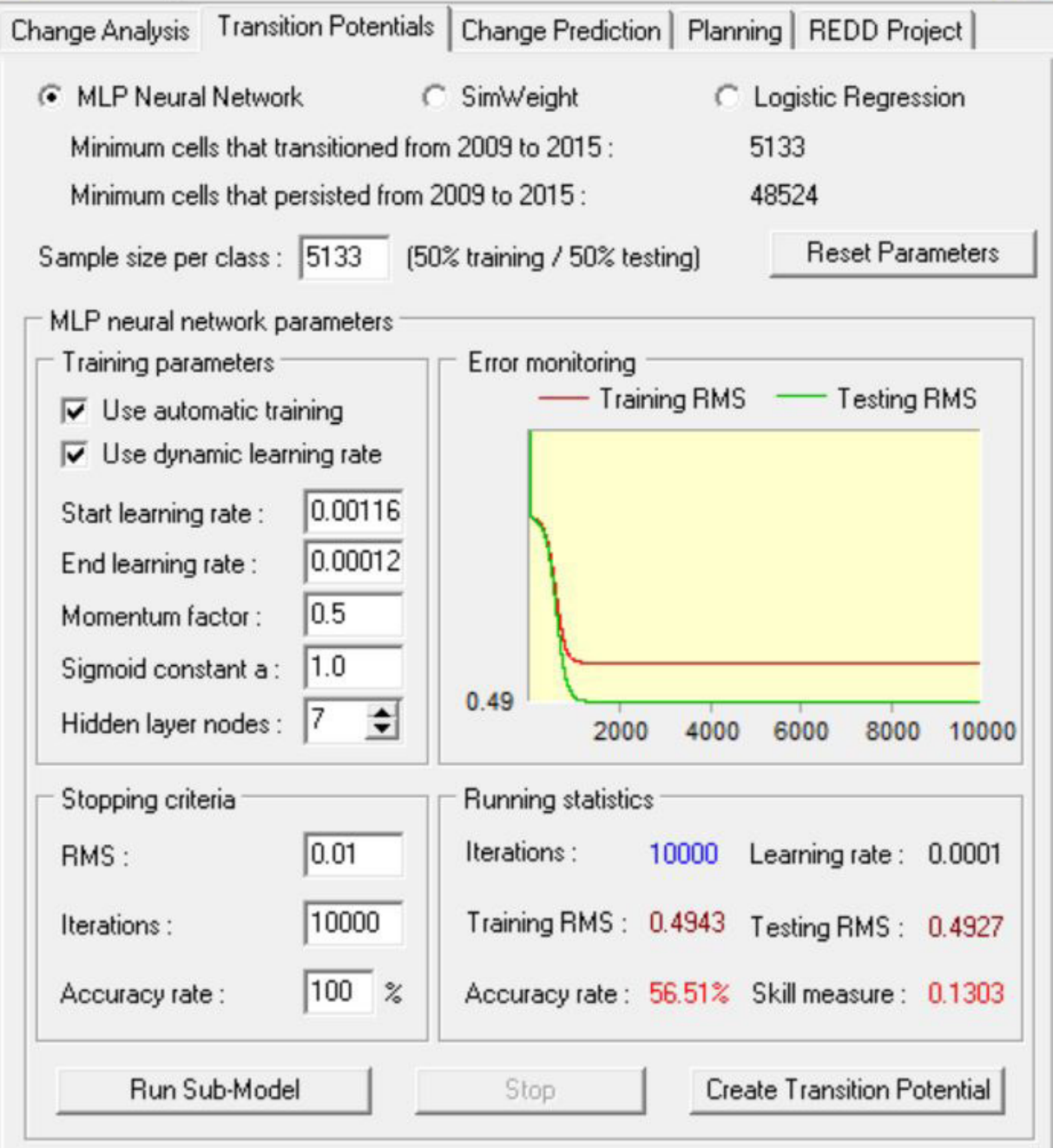

Gambar 6. Proses menjalankan model menggunakan jaringan saraf MLP 


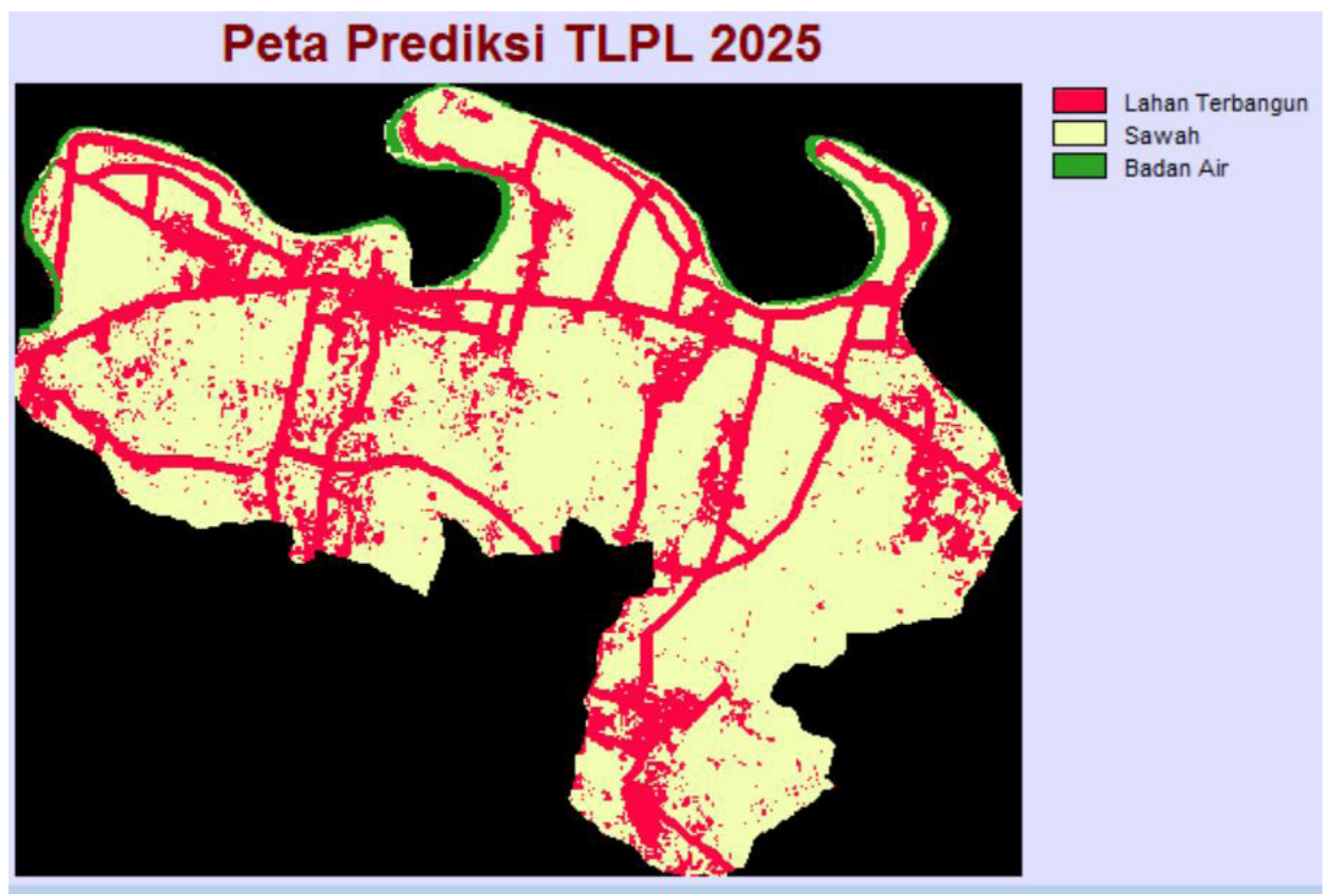

Gambar 7. Peta prediksi TLPL tahun 2025

\section{Pengolahan Data Tabular}

Berdasarkan data BPS bahwa angka produktifitas padi pada Kecamatan Kalitidu tahun 2015 sebesar $68.68 \mathrm{kwintal} /$ hektar, sehingga dapat dihitung produksi padi sebesar 31901.79 ton. Menurut informasi dari petani bahwa dalam setahun mereka melakukan panen hingga 3 kali, sehingga pada tahun 2025 diperkirakan produksi padinya mencapai 95705.37 ton. Jadi dengan menggunakan data tersebut yang kemudian dikalikan dengan angka GKG maka produksi beras Kecamatan Kalitidu di tahun 2025 sebesar 60045.55 ton.

Langkah selanjutnya adalah mendapatkan angka jumlah penduduk Kecamatan Kalitidu di tahun 2025. Dari hasil perhitungan jumlah penduduk sesuai dengan persamaan (1) maka julah penduduk pada tahun 2025 didapatkan sebanyak 52515 jiwa, nilai tersebut didapatkan dengan menggunakan laju pertumbuhan penduduk $0.6185 \%$ sesuai dengan proyeksi laju pertumbuhan dari BPS.

Untuk mendapatkan angka konsumsi beras perkapita di tahun 2025 dilakukan perkalian jumlah penduduk dengan angka konsumsi beras per kapita per tahun, sehingga nilai yang dihasilkan dari perkalian tersebut adalah $4648402 \mathrm{~kg}$ atau 4648.402 ton.

\section{KESIMPULAN}

Berdasarkan pembahasan sebelumnya bahwa dalam mendapatkan nilai produksi beras pada tahun 2025 maka yang dilakukan pertama kali adalah dengan mencari angka luasan sawah di tahun 2025. Dalam mendapatkan angka tersebut dilakukan pemodelan spasial penggunaan lahan dengan metode MLP dan rantai markov dimana hal tersebut tergabung dalam metode LCM yang berada di perangkat lunak Idrisi. Dengan melewati tahap analisa perubahan, potensi transisi, dan prediksi perubahan yang di dalamnya melibatkan variabel jalan sebagai faktor pendukung prediksi perubahan penggunaan lahan. Pada akhirnya luasan sawah pada tahun 2025 didapat dengan nilai 4644.99 hektar dengan nilai akurasi 56.51\%. Kemudian nilai tersebut dijadikan acuan dalam mendapatkan nilai produksi beras. Sesuai hasil perhitungan di atas didapatkan angka produksi beras Kecamatan Kalitidu tahun 2025 sebesar 95705.37 ton.

Setelah mendapatkan nilai produksi beras, langkah selanjutnya adalah dengan menghitung konsumsi beras per kapita di tahun 2025. Berdasarkan perhitungan didapatkan angka jumlah penduduk di tahun 2025 sebanyak 52515 jiwa, sehingga dengan angka tersebut didapatkan nilai konsumsi beras per kapita di tahun 2025 sebesar 4648.402 ton.

Dari hasil perhitungan di atas maka dapat disimpulkan bahwa nilai produksi beras lebih besar dibandingkan dengan konsumsi berasnya yang memiliki arti bahwa Kecamatan Kalitidu akan berswasembada beras di tahun 2025 nanti.

\section{UCAPAN TERIMA KASIH}

Penulis ucapkan terima kasih kepada dosen pengajar di Program Magister Ilmu Geografi, Universitas 
Indonesia atas bimbingannya serta kepada Lembaga Pengelola Dana Pendidikan (LPDP) atas dukungan dana beasiswa dalam menempuh jenjang magister.

\section{DAFTAR PUSTAKA}

Badan Pusat Statistik Kabupaten Bojonegoro. (2016). Kabupaten Bojonegoro Dalam Angka 2016. Bojonegoro: BPS Kabupaten Bojonegoro.

Eastman, R.J. (2006). IDRISI Andes, Guide to GIS and Image Processing. Worcester: Clark University.

Fuad, A., Ardiansyah, A.N., Nuraeni, N.S. (2016). Produktivitas lahan sawah dalam pemenuhan kebutuhan beras penduduk di Kecamatan Bojong Kabupaten Tegal. Prosiding Seminar Nasional Geomatika 2016. Cibinong: Badan Informasi Geospasial.

Mishra, V.N., Rai, P.K., Mohan, M. (2014). Prediction of land use change based on land change modeler (LCM) using remote sensing : A case study of Muzaffarpur (Bihar), India. Journal of the Geographical Institute "Jovan Cvijic" SASA, 64(1), 111-127.

Mishra, V.N., Rai, P.K. (2016). A remote sensing aided multi-layer perceptron-Markov chain analysis for land use and land cover change prediction in Patna district (Bihar), India. Arabian Journal of Geosciences, 9, 249.

Purwadhi, S.H.F., Kardono, P., Haryani, N.S., Poniman, A. (2015). Pengembangan Wilayah Permukiman dalam Perspektif Geospasial. Jakarta : Polimedia Publishing.

Rejekiningrum, P. (2013). Model Optimasi Surplus Beras untuk Menentukan Tingkat Ketahanan Pangan Nasional. Prosiding Seminar Nasional FMIPA-UT 2013. Tangerang Selatan: Universitas Terbuka.

Singh, S., Reddy, C. S., Pasha, S. V., Dutta K., Saranya K.R.L., Sattish, K.V. (2017). Modelling the spatial dynamics of deforestation and fragmentation using Multi-Layer Perceptron neural network and landscape fragmentation tool. Ecological Engineering, 99, 543-551.

Vega, A.P., Mas, J.F., Zielinska, A.L. (2012). Comparing two approches to land use/cover change modeling and their implication for the assesment of biodiversity loss in a deciduous forest. Environtment Modelling \& Software, 29, 11-23.

Wardani, D.W., Danoedoro, P., Susilo, B. (2016). Kajian perubahan penggunaan lahan berbasis citra satelit penginderaan jauh resolusi menengah dengan metode multi layer perceptron dan markov chain. Majalah Geografi Indonesia, 30(1), 9-18. 